\title{
Çarşı ve Mahalle Bekçilerinin Sundukları Güvenlik Hizmetinin Algılanan Kalitesine İş Doyumunun Etkisi
}

DOI: $10.26466 /$ opus.796313

$*$

\author{
Mehmet Ali Tekiner* - Uğur Demirci** - Mustafa Harputlu *** \\ * Doç., Polis Akademisi Başkanlığı, Ankara/Türkiye \\ E-Posta: malitekiner@gmail.com \\ ORCID: 0000-0002-3261-5777 \\ ** Dr., Emniyet Müdürü, Özel Güvenlik Denetleme Başkanlığı Ankara/Türkiye \\ E-Posta: ugurdemirci@yahoo.com ORCID: 0000-0002-4677-3477 \\ ***Antakya Kaymakamı, Hatay Valiliği Hatay/Türkiye \\ E-Posta: mmharputlu@gmail.com \\ ORCID: 0000-0002-9492-7792
}

Öz

Bu araştırmanın temel amacı çarşı ve mahalle bekçileri tarafından vatandaşa sunulan güvenlik hizmetinin algılanan kalitesi üzerinde iş doyumunun etkili olup olmadığını test etmektir. Araştırmanın evrenini Antalya ili Alanya ilçesinde görev yapan çarşı ve mahalle bekçileri ile burada yaşayan vatandaşlar oluşturmaktadır. Çarşı ve mahalle bekçileri için tamsayım; vatandaşlar için tesadüfi örneklem kullanılmıştır. Uygulanan anket neticesinde analize uygun çarşı ve mahalle bekçilerinden 38, vatandaşlardan 430 veri araştırmaya dahil edilmiştir. Araştırma verilerini toplamak için Weiss ve arkadaşları (1967) tarafindan geliştirilen Minesota İş Doyum Ölçeği ve Parasuraman ve arkadaşları (1988) tarafindan geliştirilen SERVQUAL ölçeği kullanılmıştır. Araştırma sonuçlarına göre iş doyumu ile hizmet kalitesi algısı arasındaki ilişkinin anlamlı olmadığı tespit edilmiştir. Araştırmada çarşı ve mahalle bekçilerinin içsel doyum düzeylerinin yüksek, dışsal ve genel doyum seviyelerinin orta düzeyde olduğ $u$ da tespit edilmiştir. Diğer taraftan, görev yaparken çarşı ve mahalle bekçilerini gördüklerini ifade eden vatandaşlarm güvenlik hizmet kalitesi algılarının yüksek olduğu, diğerlerinin ise orta düzeyde olduğu tespit edilmiştir.

Anahtar Kelimeler: Çarşı ve mahalle bekçisi, İçsel doyum, Dışsal doyum, Hizmet kalitesi algısı. 


\title{
The Effect of Job Satisfaction on The Perceived Quality of The Security Service Provided by The Bazaar and Neighborhood Wardens
}

$*$

\begin{abstract}
The main purpose of this study is to test whether job satisfaction is effective on the perceived quality of security services offered to citizens by bazaar and neighborhood wardens. The population of the study includes the bazaar and neighborhood wardens who work in Antalya city Alanya province, and citizens who resides there. Full count sample was conducted for bazaar and neighborhood wardens and random sampling was used for citizens. As a result of questionnaires, 38 data from bazaar and neighborhood wardens and 430 data from citizens were found analyzable. In this study, the job satisfaction scale developed by Weiss et al. (1967) and the SERVQUAL scale developed by Parasuraman et al. (1988) was used. According to the results of the study, it was revealed that the relationship between job satisfaction and service quality perception is not significant. In this study it was also revealed that the level of internal satisfaction of bazaar and neighborhood wardens are high, the level of external and general satisfaction of them are moderate. Moreover, it was revealed that perceived security service quality of citizens who mentioned that they saw the bazaar and neighborhood wardens while they were working are high, the others are moderate.
\end{abstract}

Keywords: Bazaar and neighborhood wardens, Internal satisfaction, External satisfaction, Service quality perception. 


\section{Giriş}

Kurumsal temelleri Osmanlının İstanbul'u Fethi dönemine dayanan bekçilik müessesesi, Cumhuriyet döneminde de "Bekçi Baba" ismiyle halka güvenlik hizmeti sunmaya devam etmiştir. 1966 yılında çıkarılan Kanunla hakları ve görevleri düzenlenen bekçilere 1970'li yıllarla birlikte verilen önem çeşitli sebeplerle azalmaya başlamış ve 1993 yılında devlete bekçi alımı durdurulmuştur. Ancak 2016 yilına gelindiğinde "yaya devriye hizmeti ile asayiş sorunlarına karşı tedbir alınabileceği ve toplumun beklentilerinin önemini benimseyen emniyet uygulamalarının çarşı ve mahalle bekçiliği uygulaması ile gerçekleşebileceği" düşüncesi çerçevesinde çarşı ve mahalle bekçisi uygulamasının tekrar başlaması kararı alınmıştır (İçişleri Bakanlığı, 2019, s.10).

Çarşı ve mahalle bekçiliği uygulamasının tekrar gündeme alınması ve faaliyete geçirilmesine ilişkin olarak olumlu ve olumsuz birçok haber yayınlanmıştır (Çobanoğlu ve Bek, 2019, s.1764). Vatandaşın, bekçilerin davranışlarından şikayetçi oldukları ${ }^{1}$, bekçilerin aşırı güç kullandığ $1^{2}$ ve bekçilerin bireylerin yaşam tarzına müdahale aracı olarak kullanılabileceğ $i^{3}$ yönünde olumsuz haberler yapılmıştır. Bu bağlamda çarşı ve mahalle bekçilerinin sunmuş oldukları güvenlik hizmetinin kalitesi ve bu kaliteyi vatandaşın nasıl algıladığı hususu gündeme gelmeye başlamıştır. Bu kapsamda yapılan araştırmalarda bekçilerin genel asayiş olaylarıyla mücadelede olumlu katkıları bulunduğu ve halk gözünde memnuniyetle karşılandıkları (Gökçe ve Kutlu, 2019) ve uygulama neticesinde vatandaşın kendisini daha fazla güvende hissettiği (İçişleri Bakanlığı, 2019) ortaya konulmuştur. Bununla birlikte bekçi teşkilatının yeniden canlandırılmasının doğru olmadığı, kendilerine tanınan yetkilerin kaygı verici olduğunu savunan araştırmalar da yayınlanmıştır. Bu nedenle Türkiye'de yeniden uygulamaya alınan çarşı ve mahalle bekçilerinin sunduğu güvenlik hizmetinin vatandaş tarafından algılanan kalite düzeyinin ortaya konulması önem taşımaktadır.

\footnotetext{
${ }^{1}$ https://www.haber3.com/quncel/vatandas-bekcilerden-sikayetci-haberi-5058732, Erişim tarihi: 10.08.2020.

${ }^{2}$ https://www.aa.com.tr/tr/turkiye/bekcilerin-ankarada-bir-aileye-karsi-asiri-guc-kullandigi-iddialarinailiskin-aciklama/1851693, Erişim tarihi: 10.08.2020.

${ }^{3}$ https://tr.sputniknews.com/columnists/202002041041328221-olaganustu-yetkilendirilmis-bekcilerhuzur-mu-yasam-tarzina-mudahale-mi-getirir/, Erişim tarihi: 10.08.2020.
} 
Müşteri beklentilerinin mevcut performans ile karşılaştırılması neticesinde oluşan, tatmin edici olan, fakat bununla aynı değerde olmayan bir tutum şeklinde tanımlanan hizmet kalitesi (Parasuraman vd., 1985) örgütlerin başarı ve başarısızlıkları üzerinde rol oynamaktadır (Berry vd., 1988, s.35). Bu nedenle kamu kurumları dahil tüm örgütler açısından hizmet kalitesinin tespiti önem taşımaktadır (Demirbağ ve Yozgat, 2016; Yılmaz, 2011; Ersöz vd., 2009). Örgütler bu şekilde sunmuş oldukları hizmetlerin tüketicilerin beklentilerini karşılayıp karşılamadığını ortaya koyarak, gerekli olması durumunda, bu hizmet kalitesi algısını yükseltecek unsurlar üzerine yoğunlaşarak gerekli tedbirleri almaktadırlar. Hizmet kalitesi algısını etkileyen çeşitli unsurlar bulunmaktadır. Alan yazında iş doyumunun hizmet kalitesi algısını etkileyen unsurlardan birisi olduğu ifade edilmektedir (Schneider ve Bowen, 1985; Johnson vd., 1994; Schlesinger ve Zornitsky, 1991; Schmit ve Allscheid, 1995). Bu bağlamda Türkiye'deki çarşı ve mahalle bekçilerinin ortaya koyduğu güvenlik hizmeti üzerinde iş doyumları etkili olabileceği öngörülebilir.

Araştırma, "Türkiye'de çarşı ve mahalle bekçileri tarafından sunulan güvenlik hizmetinin vatandaş tarafından algılanan kalitesine iş doyumları etkili midir?" sorusuna cevap bulmak amaciyla gerçekleştirilmiştir. Bu amaçla Antalya ili Alanya ilçesinde görev yapan çarşı ve mahalle bekçileri ile kendilerinden güvenlik hizmeti alan vatandaşlara, kendilerinin iş doyumu ve hizmet kalitesi algılarını tespite yönelik oluşturulmuş anket uygulanmıştır. Araştırma sonuçlarına göre çarşı ve mahalle bekçilerinin iş doyumları ile kendilerinden güvenlik hizmeti alan vatandaşların hizmet kalitesi algıları arasındaki ilişkinin anlamlı olmadığı tespit edilmiştir. Araştırmada ayrıca çarşı ve mahalle bekçilerinin içsel doyumu düzeylerinin yüksek, dışsal ve genel doyum düzeylerinin orta seviyede olduğu; kendilerinden güvenlik hizmeti alan vatandaşlardan çarşı ve mahalle bekçilerini görev başında gördüklerini ifade eden vatandaşların hizmet kalitesi algılarının yüksek, diğerlerinin ise orta seviyede olduğu tespit edilmiştir. 


\section{Kavramsal Çerçeve}

\section{Türkiye'de Çarşı ve Mahalle Bekçileri}

Bekçilik tarihi çok eskilere dayansa da, günümüz Türkiye'sindeki güvenlik yapısına yönelik ilk temelleri İstanbul'un fethiyle başlamıştır (Polis Akademisi Başkanlığı, 2019, s.13; Lévy, 2008, s.138). Osmanlıda başta İstanbul olmak üzere birçok büyük ilde ihtiyar heyetine bağlı olarak görev yapan mahalle bekçilerinin halk yaşantısında önemli ölçüde bir yeri bulunmaktaydı (Doğan,2019, s.260). Bu dönemde bekçiler mahalle halkının talebi üzerine güven usulüne göre tayin olmaktaydılar. Mahalle halkının güvenine mazhar olan bekçiler, muhtar ve imamların emrinde mahallenin asayişine katkı sağlayacak biçimde herhangi bir hırsızlık ve benzeri olayda görevlilere yardımcı olmakta; doğum, ölüm, düğün askere alma ve benzeri hallerde gerekli hizmetleri görmekteydi (Atabeyoğlu, 1993, s.125). Bekçilerin mahalle halkına özel işlerinde de yardımcı oldukları (Doğan, 2019, s.261) hatta mahalleyle ilgili her işle ilgilendikleri bilinmektedir (Şahin, 2005, s.278). Bir nevi kamu görevlisi olarak görev yapan bu bekçiler ellerinde fener ve demirli uzun sopa ile sabaha kadar sokakları dolaşarak halkın huzur ve güvenliğini sağlamaktaydılar (Gülşen, 1999, s.8). Bekçiler asayişin en alt, buna karşıllı en etkili yerini işgal etmekteydiler (Şahin, 2018, s.69). Bekçiler sokak sakinlerini yakından tanıyan konumundaydılar (Öztuna, 1978, s.190). Buna rağmen görevleri sebebiyle edindikleri bilgileri ifşa etmediklerinden mahalle sakinleri tarafindan saygıyla karşılanmaktaydılar. Bu sosyallikleri sebebiyle de bekçilerin toplum hayatında küçümsenmeyecek yerleri bulunmaktaydı. Çocuklar ve gençler kendisini "Bekçi Baba" olarak tanırdı (Şahin, 2018, s. 57-70). Evliya Çelebi'ye (1898) göre 17.yüzyılın ortalarında İstanbul'da 12.000 bekçi görev yapmaktadır. Bu dönemin bekçileri memleketlerinde veya buna yakın yerlerde görev yaptıklarından içinde bulundukları halkın sosyal, psikolojik, kültürel ve ekonomik şartları hakkında bilgi sahibi olan ve yöresel farklılıkları anlayabilen kişilerdi (Doğan, 2019, s.262).

Bekçilerin durumlarının iyileştirilmesi ve daha kurumsal bir yapıya kavuşturulması açısından Osmanlı döneminde ilk düzenleme 1909 yılında 41 maddelik bir kanun metni olan "Mahalle Bekçileri Nizamnamesi" ile gerçekleştirilmiştir. Daha sonrasında bu düzenlemelere ek maddeler getirilerek 
1914 yılında "Çarşı ve Mahallat Bekçileri Hakkında Kanun-1 Muvakkat" yayınlanmıştır. Bu düzenlemeler bekçilerin özlük hakları başta olmak üzere silah kullanma gibi birçok konuya açıklık getirmiştir (Doğan, 2019, s.266). Bu haldeki bekçilik kurumu Osmanlıdan Cumhuriyet dönemine miras kalarak 1960'lı yıllara kadar uygulanmıştır (Polis Akademisi Başkanlığı, 2019, s.17). Bu dönemde her ne kadar bekçilerin muhtaç kişilere, hastalara ve sarhoşlara yardım; dügün, sünnet ve cenaze işlerine katılım; halka rahatsızlık verenleri karakola bildirme; dilenci ve serserilerin toplanması gibi bazı hususları yerine getirmelerine izin verildiği görülse de, bekçilerin genel asayişe dair görevlerinin ön plana çıkarak halk arasındaki sevecen ve yardımsever imajının azaldığ1 iddia edilmektedir (Doğan, 2019, s.269-270)

Cumhuriyet döneminde bekçilerin tayin, ücret, izin ve görevlerine ilişkin olarak 1966 yılında 772 sayılı Çarşı ve Mahalle Bekçileri Kanunu ile düzenleme gerçekleştirilmiştir. Bekçiler bu Kanun ile en büyük mülki amirin emrinde, genel zabıtaya yardımcı, silahlı bir kuruluş olarak tanımlanmıştır (Polis Akademisi Başkanlığı, 2019, s.16). 772 sayılı Kanunun 3.maddesinde ise çarşı ve mahalle bekçilerinin genel kolluk görevlilerinin derhal müdahale imkanı bulunmayan hallerdeki asayişin sağlanmasına yönelik görevleri ve genel kolluk görevlilerine yardım yönünden görevlerinin yanında mahalle sakinlerinin istirahat, sağlık ve selametini sağlamaya yönelik yükümlülüklerinin de bulunduğu ifade edilmiştir. Bu bağlamda bekçiler görevli oldukları mıntıka dahilinde hastalanan, kazaya uğrayan ve yardıma muhtaç kişilere yardım etmek; kimsesizleri, sakatları, alil ve acizleri veli ve vasilerine teslim etmek üzere karakola teslim etmek; görevli olduğu yerlerde kendine başvuranlara bilgi vermek; doğum, ölüm, hastalık ve kaza gibi önemli ve acil hallerde imkanı ölçüsünde yardımda bulunmak; elektrik, havagazı, su ve kanalizasyon gibi hizmetlerdeki sıkıntıları, sokakları pisletenleri en yakın kolluğa bilgi vermekle sorumlu tutulmuşlardır (Şahin, 2018, s.204). Bu çerçevede bekçilerin mikro düzeyde halkın sorunlarıyla birebir ilgili olmalarının amaçlandığı anlaşılmaktadır. Ancak bekçilerin 772 sayılı Kanun döneminde bekçilik görevinin dışında mahalle halkıyla irtibatı kalmamış ve "mahallenin gediklisi" olmaktan uzaklaşmıştır (Koçu, 1973, s.14). Bununla birlikte 1970'li yıllarla birlikte çarşı ve mahalle bekçilerine önem verilmemeye başlanmış ve bekçi alımları azaltılmıştır (Çobanoğlu ve Bek, 2019, s.1760). 1993 yılında ise bekçilik müessesesinin zamana ayak uyduramadığı değerlendirilerek alımı durdurulmuştur (Polis Akademisi Başkanlığı, 2019, s.6). Tablo 1'de görüleceği üzere 
2017 yılına kadar Emniyet Genel Müdürlüğü bünyesindeki çarşı ve mahalle bekçilerinin genel personel sayısına oranı devamlı gerilemiştir.

Tablo 1. Emniyet Genel Müdürlüğü Bünyesinde Görev Yapan Çarşı ve Mahalle Bekçilerinin Genel Personel Sayısina Oranı.

\begin{tabular}{llll}
\hline Y11 & EGM Personeli & Çarşı ve Mahalle Bekçisi & Oran $\%$ \\
\hline $\mathbf{1 9 9 1}$ & 147.418 & 21.046 & 14,28 \\
\hline $\mathbf{1 9 9 5}$ & 146.517 & 16.958 & 11,57 \\
\hline $\mathbf{2 0 0 3}$ & 173.342 & 9.122 & 5,26 \\
\hline $\mathbf{2 0 1 2}$ & 256.239 & 4.058 & 1,58 \\
\hline $\mathbf{2 0 1 4}$ & 270.791 & 3.546 & 1,31 \\
\hline $\mathbf{2 0 1 5}$ & 273.006 & 3.109 & 1,14 \\
\hline $\mathbf{2 0 1 6}$ & 273.846 & 3.937 & 1,44 \\
\hline $\mathbf{2 0 1 7}$ & 267.992 & 4.653 & 1,75 \\
\hline $\mathbf{2 0 1 8}$ & 292.208 & 11.398 & 3,90 \\
\hline
\end{tabular}

Çobanoğlu ve Bek, 2019:1761

Yaya devriye hizmeti ile asayiş sorunlarına karşı önleyici tedbir alınabileceğini ve toplumun beklentilerinin önemini benimseyen emniyet uygulamalarının, çarşı ve mahalle bekçiliği uygulaması ile gerçekleşebileceği düşüncesi çerçevesinde kentlerin asayiş sorunlarına çözüm bulabilmek amacıyla 2016 yılında çarşı ve mahalle bekçiliği uygulamasına tekrar geçilmesi kararlaştırılmıştır (İçişleri Bakanlığı, 2019, s. 10). Yapılan yeni alımlarla Türkiye'de 2019 yılı Mart ayı itibariyle çarşı ve mahalle bekçisi sayısı 21.311'e yükselerek tüm ülkede faaliyete geçmiştir (Polis Akademisi Başkanlığı, 2019:6). Kentsel alanların büyümesiyle birlikte Türkiye' de çarşı mahalle bekçilerinin istidam alanlarının daha fazla büyüme potansiyeli bulunduğu ifade edilmektedir (Barbak, 2017, s. 241).

Bekçilik müessesesinin tekrar gündeme gelmesiyle birlikte medyada olumlu ve olumsuz birçok haber yapılmıştır (Çobanoğlu ve Bek, 2019:1764). Öte yandan yeni çarşı ve mahalle bekçileri üzerine yapılan araştırmalarda bekçilerin özellikle mala karşı işlenen suçlar, fuhuş, uyuşturucu kullanımı/dağıtımı suçları ile genel asayiş olaylarıyla mücadele kapsamında olumlu katkılar sağladığı ve halk gözünde memnuniyet yarattığı ifade edilmiştir (Gökçe ve Kulu, 2019, s. 160). İçişleri Bakanlığı tarafından 2019 yılında gerçekleştirilen saha incelemesi neticesinde de toplumun bekçilik müessesesine olumlu yaklaştığı, bu uygulama ile toplumun kendisini güvende hissettiği, bekçilerin temas ettiği sosyal alanlardan olumlu geri dönüşler alındığı ve 
bekçilerin asayiş olaylarının önlenmesinde önemli katkılarının bulunduğu tespit edilmiştir (İçişleri Bakanlığı, 2019). Polis Akademisi Başkanlığı tarafından 2019 yılında hazırlanan bir raporda da bekçilik sisteminin başta İstanbul olmak üzere Türkiye genelinde asayişe karşı suçlarla mücadelede önemli katkıları olduğu ifade edilmektedir (Polis Akademisi Başkanlığı, 2019). Bu çalışmaların ortaya koyduğu neticelerin aksine, bekçi teşkilatının yeniden canlandırılmasının yerinde olmadığı, bekçilere tanınan yetkilerin kaygı verici olduğunu ve bu yetkilerin kapsamının dar tutulması gerektiğini savunan araştırmacilar da bulunmaktadır (Erman vd., 2020, s.39).

\section{İş Doyumu}

İş hayatından duyulan haz (Vieira, 2005: 39) olarak kısaca tanımlanabilecek olan iş doyumunu Locke (1976), kişinin işini genel olarak değerlendirmesi sonucunda ortaya çıkan duygusal durum olarak tanımlamaktadır. İş doyumu bireyin işine karşı duygusal, bilişsel ve değerlendirici tutumudur (Baron ve Greenberg, 1990, s.160) ve bireyde çalışma hayatı veya söz konusu kişi ile çalıştığı iş yeri koşulları arasındaki uyumun bir sonucu olarak ortaya çkar (Ugboro ve Obeng, 2000, s.254). Bu bağlamda Churchill ve arkadaşları (1974) iş doyumunu, çalışma ortamından kaynaklanan, çalışanı motive edici veya kendisinde hayal kırıklığı yaratıc tüm faktörlerin birleşimi şeklinde tanımlamaktadır. Aktaş ve Şimşek ise (2015), bireyin işine ve işinden memnuniyet oranına ilişkin duygu ve düşünceleri şeklinde iş doyumunu ifade etmektedir.

İş doyumu bireysel ve örgütsel birçok faktörden etkilenmektedir (Özgen vd., 2002; Erdoğan, 1996). Kişilik, iş tecrübesi, hizmet süresi, eğitim düzeyi, değer yargıları, beklentiler, yaş, cinsiyet ve zeka düzeyi iş doyumu etkileyen bireysel faktörler arasında sayılabilirken; işin toplumdaki önemi, işin zorluk derecesi, örgüt kültürü, ücret, terfi, ödüllendirme, çalışma koşulları, liderlik durumu, çalışanların kararlara katılım durumu ve iş güvenliği gibi unsurlar da iş doyumunu etkileyen örgütsel faktörler arasında sayılabilir (Asunakutlu ve Avcl, 2010, s. 98; Karataş ve Güleş, 2010, s.76; Başaran, 2000).

İş doyumunun örgütlerin etkinlik ve verimlilikleri üzerinde etkili olduğu (Şimşek vd., 2007, s.71) bilindiğinden, yöneticiler ve araştırmacılar tarafından özellikle üzerinde durulan bir husus olarak karşımıza çıkmaktadır. Alan yazın incelendiğinde iş doyumunun, örgütlerin etkinlik ve verimlilikleri üze- 
rinde etkili olduğu bilinen örgütsel bağlllık, mesleki bağlllık (Karataş ve Güleş, 2010; Çetin, 2006), örgütsel güven (Semercioğlu vd., 2012), örgütsel vatandaşlık davranışı (Yılmaz, 2012), iş yaşam kalitesi (Aksoy Zor, 2019), işe angaje olma (Arslan ve Demir, 2017), örgütsel özdeşleşme (Efraty vd., 1991), motivasyon (Orhaner ve Mutlu, 2018) ve tüketici tatmini (Jeon ve Choi, 2012; Brown ve Lam, 2008; Scheneider ve Bowen, 1985) gibi birçok iş tutumuyla da pozitif yönlü ilişkili olduğu görülmektedir. Ayrıca iş doyumu çalışanların tükenmişlik düzeylerini (Kış vd., 2016) ve iş streslerini azaltır, işten ayrılma niyetlerini (Turunç vd., 2010) düşürür.

\section{Hizmet Kalitesi ve Ölçümü}

Performans ve ideal arasındaki fark (Teas, 1994) olarak ifade edilebilecek hizmet kalitesi, sunulan hizmetin müşteri talep ve beklentilerini ne kadar karşıladığı ile ilgilidir (Lewis, 1993). Hizmet kalitesi, müşteri gereksinimi ve beklentileri, bunların doğrultusunda hizmetin sahip olması gereken nitelikler ile hizmetin bu özellikler ve niteliklere sahip olma derecesi şeklinde ifade edilmektedir (Esin, 2002). Han ve Baek (2004, s.208), bir işletmenin ve onun tarafından sunulan hizmetlerin göreli olarak müşterilerde bıraktığı genel izlenim olarak tanımlamaktadır. Parasuraman ve arkadaşları (1985) ise hizmet kalitesini, müşteri beklentilerinin mevcut performansla karşılaştırılması sonucu oluşan, tatmin edici olan, fakat bununla aynı değerde olmayan bir tutum şeklinde tanımlayarak, müşterilerin kişisel değerlendirmelerinin ayn zamanda algilanan hizmet kalitesini temsil ettiğini ifade etmektedir. Hizmet kalitesi müşterinin hizmeti satın almasından sonra o hizmetten elde ettiklerinin kendisinde yaratmış olduğu duyguyu işaret eder ve söz konusu hizmetten müşterinin tatmin olup olmadığını ifade eder (Çiçek ve Doğan, 2009, s.203). Bu açıdan hizmet kalitesi, müşterilerin istek ve beklentileri ile bu yöndeki algılarının karşılaştırılmasıdır (Zeithaim vd., 1990). Müşterilerin hizmet kalitesine ilişkin bu algıları da, hizmete erişmeden önce kendilerinde oluşan beklentileri ile gerçekleşen deneyimlerini karşılaştırmaları neticesinde oluşmaktadır (Parasuraman vd., 1988).

Hizmet kalitesi, örgütlerin başarı ve başarısızlığı üzerinde rol oynamaktadır (Berry vd., 1988: 35). Yüksek hizmet kalitesi, yüksek pazar payı, yüksek verimlilik ve karlılık, yeni müşteri ile var olan müşterilerde sadakat anlamına 
gelmektedir (Zeithaml, vd., 1990, s. 2; Christina ve Gursoy, 2009, s.247; Murdick vd., 2000, s.329). Bununla birlikte gelişmiş hizmet kalitesi, azalan maliyetler, azalan düzeltici faaliyetler ile daha az şikâyet ve azalan iş gören devir oranıyla sonuçlanmaktadır (Devlin ve Dong, 1994, s.5). Düşük hizmet kalitesi ise tatmin olmayan müşteri, düşük satın alma davranışı ve negatif performansla sonuçlanmaktadır (Bound vd., 1994; Roger vd., 1994).

Hizmet kalitesi kamu kurumları için de önemlidir. 2000'li yıllarla birlikte gerçekleşen yeni kamu yönetimi anlayışı çerçevesinde piyasa yöntemleri ve rekabetçi mekanizmaların kamu kuruluşlarında da uygulanmaya başlaması neticesinde kamudan hizmet alanların memnuniyetinin esas alındığı bir hizmet anlayışı ön plana çıkmıştır (Özer, 2005). Yeni kamu yönetimi yaklaşımının en önemli unsurlarından birisi vatandaş odaklılıktır (Kurt ve Yaşar Uğurlu, 2007, s.87). Bu çerçevede kamu kurumlarınca ortaya konulan hizmetin kalitesi ve bu hizmeti alan vatandaşların memnuniyet düzeyi işletmelerde olduğu gibi kamu kurumları açısından da başarı ve başarısızlık şeklinde bir performans göstergesi olarak ele alınmaya başlanmıştır. Kamu kurumları yeni kamu yönetimi yaklaşımı çerçevesinde hizmetlerini, vatandaş memnuniyet ve taleplerine göre şekillendirmektedirler. $\mathrm{Bu}$ nedenle kamu alanında da hizmet kalitesinin ölçülmesine ilişkin araştırmalara önem verilmektedir (Demirbağ ve Yozgat, 2016; Yılmaz, 2011; Yağcı ve Duman, 2011; Ersöz vd., 2009; Akbaba vd., 2006). Vatandaş odaklı kamu yönetimi, hizmetlerin vatandaşa kaliteli olarak zamanında sunulmasını (Eren, 2003, s.66) ve sürekli iyileştirmeyi (Yayman, 1997: 143) gerekli kılmaktadır.

Örgütler tarafından sunulan hizmetin kalitesini etkileyen çeşitli unsurlar bulunmaktadır. Parasuraman ve arkadaşları (1990, s. 20-28) hizmet kalitesini etkileyen faktörleri güvenilirlik, heveslilik, yeterlilik, erişebilirlik, saygı, iletişim, inanılırlık, güvenlik, müşteriyi anlamak ve fiziksel varlıklar şeklinde ifade etmektedirler. Örgütler taahhüt ettiği hizmeti doğru ve güvenilir bir şekilde yerine getirebilmelidir (Dalgıç, 2013, s.21). Örgüt çalışanları hizmeti sağlama hususunda istekli olmalıdırlar (Gülmez ve Kitapçı, 2008, s.167). Örgüt ortaya koyduğu hizmeti sağlayabilmesi için yeterli kabiliyete ve bilgiye sahip olmalıdır (Çelik, 2010, s.29). Örgütün sağladığı hizmete müşteriler sorunsuz ulaşabilmelidirler (Dalgıç, 2013, s.23). Örgüt çalışanları müşterileri dinlemeli, onların taleplerine karşı müşteri özelliklerini dikkate alarak saygılı davranmalıdır (Parasuraman vd., 1985, s.47). Örgüt inandırıcılık ve dürüstlük gibi değerlere sahip olmalıdır (Dalgıç, 2013, s.24). Örgüt ve çalışanları gizliliğe 
önem vermelidirler (Altınel, 2009 Çelik, 2010). Örgütün sahip olduğu fiziksel olanaklar ile çalışanların kullandıkları ekipman ile giyim kuşamları olumlu imaj yaratacak şekilde ortaya konabilmelidir (Çiftçi, 2006, s.19).

Soyut, stoklanamaz ve heterojen bir yapiya sahip olan hizmetin kalitesini bir performans göstergesi olarak ele alan gerek özel sektör gerekse de kamu kurumları için sundukları hizmetin kalitesinin ölçülmesi önemlidir. Örgütler ancak bu şekilde sunmuş oldukları hizmetlerin tüketicilerin beklentilerini karşılayıp karşılamadığını anlayarak ileriye dönük tedbirler alabilmektedirler. Hizmet kalitesinin ölçümü müşteri memnuniyetinin belirlenmesiyle mümkün olabilmektedir (Altan vd., 2003) ve bu ölçüme ilişkin alan yazında farklı modeller geliştirilmiştir (Sasser, Olsen ve Wyckof, 1978; Lehtinen ve Jarmo, 1983; Grönross, 1983; Parasuraman, Zeithaml ve Berry, 1985; Normann, 1991; Doyle ve Stern, 2006; Kotler ve Keller, 2016). Bunların içerisinde en tanınanı ve kullanılanı Parasuraman ve arkadaşları (1985) tarafından geliştirilen 5 boyutlu modeldir. Bu boyutlar "fiziksel varlıklar, güvenilirlik, yanıt verebilirlik, güvence ve anlayış" şeklinde sıralanabilir (Demirbağ ve Yozgat, 2016: 80). Parasuraman ve arkadaşları (1985) hizmet kalitesini, beklenti ve algılanan performans arasındaki farkın nedeni şeklinde tanımlamışlardır. Bu bağlamda hizmet alanların bu hizmete ilişkin beklentileri, aldıkları hizmetten yüksek olduğunda, algilanan hizmet kalitesi tatminsizlik yaratacaktır. Beklenen hizmetin algılanan hizmetle aynı olması durumunda, algilanan hizmet kalitesi tatmin edici olacaktır. Algilanan hizmet beklenen hizmetten yüksek olması durumunda ise üstün kalitede hizmet sağlanmış olmaktadır (Parasuraman vd., 1985, s.48-49). Bu modelde yöneticilerden, müşteri veya vatandaş tarafından algılanan hizmet kalitesinin belirlenerek tecrübe edilen hizmetin geliştirilmesine yönelik çalışmalar yapması vurgulanmaktadır (Demirbağ ve Yozgat, 2016, s. 81).

\section{İş Doyumu ve Hizmet Kalitesi İlişkisi}

İş doyumu yüksek olan çalışan, müşterinin aldığı hizmete ilişkin algısını şekillendirebilmektedir (Spiro ve Weitz, 1990). Alan yazında çalışan iş doyumu ile müşteri memnuniyeti arasında ilişki bulunduğu, iş doyumunun müşteri memnuniyetini pozitif yönlü etkilediğini ortaya koyan çalışmalar bulunmaktadır (Mendoza ve Maldonado, 2014; Chi ve Gürsoy, 2009; Brown ve Lam, 2008; Payne ve Webber, 2006; Homburg ve Stock, 2004; Ugboro ve Obeng, 
2000; Schmit ve Allscheid, 1995; Johnson vd., 1994; Schlesinger ve Zornitsky, 1991; Schneider ve Bowen, 1985). Ancak, bu araştırma sonuçlarının tersine iş doyumu ile müşteri memnuniyeti arasında negatif yönlü ilişki bulunduğunu (Silvestro ve Cross, 2000) ortaya koyan araştırmalar bulunduğu gibi bu iki değişken arasında ilişki bulunmadığını ortaya koyan araştırmalar da bulunmaktadır (Adcock, 1999; Brown ve Mitchell, 1993). Diğer taraftan iş doyumu ile müşteri memnuniyeti arasındaki ilişkide düzenleyici (moderatör) etkiye sahip değişkenler de tespit edilmiştir (Jeon ve Choi, 2012).

Tüm bu alan yazın incelemesi neticesinde araştırmanın hipotezi aşağıdaki şekilde oluşturulmuştur:

H1. Çarşı ve mahalle bekçileri tarafından sunulan güvenlik hizmetinin vatandaş tarafından algılanan kalitesine iş doyumlarının etkisi vardır.

\section{Yöntem}

\section{Araştırmanın Amacı ve Modeli}

Bu araştırmanın amacı çarşı ve mahalle bekçileri tarafından sunulan güvenlik hizmetinin vatandaş tarafından algılanan kalitesine iş doyumlarının etkili olup olmadığını test etmektir. Nicel paradigma çerçevesinde gerçekleştirilen çalışmanın deseni ilişkisel araştırma şeklinde belirlenmiştir. Bu amaçla Antalya ili Alanya ilçesinde görev yapan çarşı ve mahalle bekçilerine kendilerinin iş doyumlarını belirlemek üzere; bu bekçilerin güvenlik hizmeti sunduğu vatandaşlara da kendilerinin güvenlik hizmet kalitesi algıların belirlemek üzere ilgili ölçekleri içeren anket uygulanmıştır. Vatandaşların aldıkları hizmete ilişkin kalite algılarında çarşı ve mahalle bekçileriyle karşılaşma durumlarının fark yaratıp yaratmadığını tespit etmek amacıyla kendilerine ayrıca bir soru yöneltilmiştir. Yapılan alan yazın incelemesi neticesinde aşağıdaki araştırma modeli oluşturulmuştur.

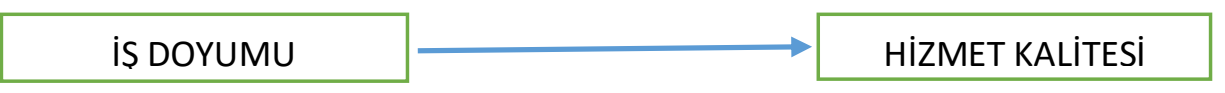

Şekil 1. Model 


\section{Evren ve Örneklem}

Bu araştırmanın evrenini Antalya ili Alanya ilçesinde görev yapan çarşı ve mahalle bekçileri ile bu bekçilerin güvenlik hizmeti sunduğu vatandaşlar oluşturmaktadır. Alanya'da Ekim 2019 tarihi itibariyle 47 çarşı ve mahalle bekçisi görev yapmaktadır ve Alanya' da 312.319 vatandaş yaşamaktadır.

Araştırmanın bağımlı ve bağımsız değişkenlerinin kendine has özellikleri sebebiyle bu araştırmada iki ayrı örneklem kullanılmıştır. Böylelikle, hem araştırma amacına yönelik doğru bilginin doğru kitleden toplanması amaçlanmış, hem de özellikle davranışla ilgili araştırmaların temel problemlerinden birisi olan ortak metod varyansından kaynaklanan ölçme hatalarının (Podsakoff vd., 2003; Podsakoff vd., 2012) önüne geçmek amaçlanmıştır. Bu bağlamda araştırmanın bağımsız değişkeni olan iş doyumunun tespit edilmesinde çarşı ve mahalle bekçilerinin tümüne ulaşabilme olanağının bulunması sebebiyle tam sayım örneklem; araştırmanın bağımlı değişkeni olan hizmet kalitesinin tespit edilmesinde ise güvenlik hizmeti alan tüm vatandaşlara ulaşma imkanının bulunmaması sebebiyle tesadüfi örneklem kullanılmıştır. Hazırlanmış olan anketler çarşı ve mahalle bekçilerine dağıtılmış ve kendileri tarafından doldurulması istenmiştir. Vatandaşlar için hazırlanan anketler ise yüz yüze doldurulmuştur. Araştırma verileri 2019 yılı Ekim ayında bir aylık bir sürede toplanmıştır. Bu süre sonunda 38 çarşı ve mahalle bekçisinden ve 430 vatandaştan veri elde edilmiştir. Yazıcıoğlu ve Erdoğan (2004, s.50) 1.000.000'luk bir evren için .005 anlamlılık düzeyi için 384 örneklemin yeterli olduğunu ifade etmektedir. Bu bağlamda 430 vatandaştan elde edilen verinin evreni temsil edebileceği değerlendirilmiştir.

\section{Veri Toplama Araci}

Araştırmada veri toplama aracı olarak anket formundan yararlanılmıştır. Anket, katılımcıların iş doyumlarını tespite yönelik Weiss ve arkadaşları (1967) tarafından geliştirilen Minnesota İş Doyum Ölçeği ile Parasuraman ve arkadaşları (1988) tarafından geliştirilen SERVQUAL ölçeği kullanılmıştır.

Minnesota iş doyum ölçeği, Oran (1989) tarafından Türkçe'ye çevrildikten sonra güvenilirliği ve geçerliliği çok sayıda araştırmada test edilerek kullanılmıştır (Hançer, 2003; Demirci, 2019; Akgündüz, 2013; Ordu, 2016). 100 soruluk ve 20 soruluk iki ayrı formu bulunan ölçeğin içsel, dışsal ve genel doyum 
düzeyini belirleyecek şekilde iki alt boyutu bulunmaktadır. Bu araştırmada 20 soruluk kısa formu kullanılmıştır. Orijinal ölçeğin güvenilirlik katsayısı $.83^{\prime}$ tür. Bu araştırmada kullanılan ölçeğin Cronbach Alfa katsayısı .635 olarak tespit edilmiştir. Ölçeğin güvenilirlik derecesinin kabul edilebilir değerler içerisinde olduğu görülmektedir (Kılıç, 2016; George ve Mallery, 2003). Ayrıca yapılan normallik testi neticesinde tüm değerlerin $+1,5$ ile $-1,5$ arasında gerçekleştiği görülmüştür. Bu haliyle verilerin normal dağıldığı kabul edilmiştir (Tabachnick ve Fidell, 2013).

SERVQUAL ölçeği hizmet kalitesini ölçmek amacıyla oluşturulmuştur. 22 sorudan oluşan ölçeğin ilk bölümü tüketicinin hizmet işletmesinden beklentilerini, ikinci bölüm ise tüketicinin işletmeden algıladığı performansı ölçmektedir. Ölçek kamu sektöründe de kullanılmaktadır (Brysland ve Curry, 2001; Wisniewski, 2001). Ayrıca ölçek Türkçe'ye çevrilerek geçerliliği ve güvenilirliği test edildikten sonra birçok araştırmada kullanılmıştır (Hassan, 2019; Altan ve Atan, 2004;Yücel, 2013; Yılmaz vd., 2007). Orijinal ölçeğin güvenilirlik katsayısı .92' dir (Parasuraman vd., 1988). Bu araştırmada kullanılan ölçeğin Cronbach Alfa katsayısı .919 olarak tespit edilmiştir. Ayrıca yapılan normallik testi neticesinde tüm değerlerin $+1,5$ ile $-1,5$ arasında gerçekleştiği görülmüştür. Bu haliyle verilerin normal dağıldığı kabul edilmiştir (Tabachnick ve Fidell, 2013).

\section{Bulgular ve Analiz}

\section{Çalışmaya Katılanlarn Demografik Özellikleri}

Çalışmaya katılan çarşı ve mahalle bekçilerinin tümü erkektir. Türkiye'de kadın çarşı ve mahalle bekçisi bulunmamaktadır. Çalışmaya katılan çarşı ve mahalle bekçilerinin 3'ü $(\%$ 7,9) 18-23 yaş arasında, 27'si (\%71,1) 24-29 yaş arasında ve 8'i (\%21,1) 30-35 yaş arasındadır. Bu katılımcıların 11'i (\%28,9) lise, 4'ü (\% 10,5) ön lisans, 22'si $(57,9)$ lisans ve 1'i $(\% 2,6)$ lisansüstü mezundur. Çarşı ve mahalle bekçilerinin tümü 5 yıl ve altında çalışma süresine sahiptir.

Çalışmaya katılan vatandaşların 315'i (\%73,3) erkek, 115'i (\%26,7) kadındır. Bu katılımcıların 65'i (\%15,1) 18-23 yaş arasında, 90'1 (\%20,9) 24-29 yaş arasında, 95'i (\%22,1) 30-35 yaş arasında ve 180'i (\%41,9) 36 ve üstü yaştadır. Katılımcların 50'si $(\% 11,6) 1$ yıl ve altı sürede, 130'u (\%30,2) 2-5 yıl arasında, $90^{\prime} 1(\% 20,9)$ 6-10 yıl arasında ve 160'1 $(\% 37,2) 11$ yıl ve üzerinde süredir aynı 
mahallede oturduğunu ifade etmektedir. Katılımcların 60'1 (\%14) ilköğretim, 190'1 (\%44,2) lise, 80'i (\%18,6) ön lisans, 80'i $(\% 18,6)$ lisans ve 20'si (\%4,7) lisansüstü mezundur. Katılımcıların 260'1 $(\% 60,5)$ çarşı ve mahalle bekçisini hizmet verirken görmüş, 170'i $(\% 39,5)$ ise görmemiştir.

\section{Çarşı ve Mahalle Bekçilerinin İş Doyumu Düzeyleri}

Araştırmaya katılan çarşı ve mahalle bekçilerinin iş doyumu düzeyleri Tablo 2'de sunulmuştur.

Tablo 2. Çarşı ve Mahalle Bekçilerinin İş Doyumu Düzeyleri

\begin{tabular}{llll}
\hline $\begin{array}{l}\text { Çarşı ve mahalle bekçi- } \\
\text { leri }\end{array}$ & Katılımcı sayısı & Ortalama & Standart sapma \\
\hline İş doyumu & 38 & 3,26 &, 22622 \\
\hline İçsel doyum & 38 & 3,41 &, 20576 \\
\hline Dişsal doyum & 38 & 3,05 &, 34561
\end{tabular}

Tablo 2 incelendiğinde araştırmaya katılan çarşı ve mahalle bekçilerinin genel iş doyumu düzeylerinin ve dışsal doyum düzeylerinin orta seviyede olduğu, içsel doyum düzeylerinin ise yüksek seviyede olduğu anlaşılmaktadir.

\section{Vatandaşlarnn Güvenlik Hizmet Kalitesi Algısı}

Araştırmaya katılan vatandaşların çarşı mahalle bekçileri tarafından sunulan güvenlik hizmeti kalite algıları Tablo 3' de sunulmuştur.

Tablo 3. Çarşı ve Mahalle Bekçileri Tarafindan Sunulan Güvenlik Hizmetinin Vatandaş Tarafindan Algilanan Kalitesi

\begin{tabular}{|c|c|c|c|c|}
\hline \multirow{4}{*}{ 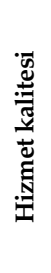 } & Vatandaş & Katılımcı sayısı & Ortalama & Standart sapma \\
\hline & Genel & 430 & 3,34 & 64401 \\
\hline & $\begin{array}{l}\text { Çarşı mahalle bekçisini hiz- } \\
\text { met verirken gördügünü } \\
\text { ifade eden }\end{array}$ & 260 & 3,56 & ,03836 \\
\hline & $\begin{array}{l}\text { Çarşı mahalle bekçisini hiz- } \\
\text { met verirken görmediğini } \\
\text { ifade eden }\end{array}$ & 170 & 2,99 & ,03985 \\
\hline
\end{tabular}


Tablo 3 incelendiğinde araştırmaya katılan vatandaşların çarşı ve mahalle bekçilerinden almış oldukları güvenlik hizmetine ilişkin kalite algılarının orta düzeyde olduğu anlaşılmaktadır. Bununla birlikte çarşı ve mahalle bekçisini görev yaparken görmüş olan vatandaşların güvenlik hizmet kalitesi algılarının yüksek, görmemiş olanların ise orta düzeyde gerçekleştiği anlaşılmaktadır. Bu iki gruba ilişkin sonuçların farklılaşıp farklılaşmadığına ilişkin yapılan t Testi sonuçları Tablo 4'de sunulmuştur.

Tablo 4. Çarşı ve Mahalle Bekçisini Görev Yaparken Gören Vatandaşlarile Görmeyenlerin Güvenlik Hizmet Kalitesi Algılarnna İlişkin t Testi Sonuçları

\begin{tabular}{|c|c|c|c|c|c|}
\hline Hizmet kalitesi & $\mathbf{N}$ & $\mathrm{X}$ & Ss & $t$ & $p$ \\
\hline $\begin{array}{l}\text { Çarş1 ve mahalle bekçisini } \\
\text { hizmet verirken gören }\end{array}$ & 260 & 3,56 & 61861 & 10,274 &, 000 \\
\hline $\begin{array}{l}\text { Çarş1 ve mahalle bekçisini } \\
\text { hizmet verirken görmeyen }\end{array}$ & 170 & 2,99 &, 51953 & & \\
\hline
\end{tabular}
$\mathrm{p}<.05$

Tablo 4'deki t Testi sonuçlarına göre \% 95 güven aralığında gerçekleştirilen analiz neticesinde significant değerinin $(p<.05)$ anlamlı olduğu görülmektedir. Bu sonuçlara göre çarşı ve mahalle bekçilerinin hizmet verdikleri esnada vatandaş tarafından görülmesi, o vatandaşların hizmet kalitesi algılarında anlamlı değişikliğe yol açtığ

\section{Çarşı ve Mahalle Bekçileri Tarafından Sunulan Güvenlik Hizmetinin Vatan- daş Tarafından Algılanan Kalitesine İş Doyumlarının Etkisi}

Çarşı ve mahalle bekçilerinin iş doyumlarının, kendileri tarafından sunulan güvenlik hizmetinin vatandaş tarafindan algılanan kalitesine etkisi olup olmadığını tespit etmek üzere regresyon analizi gerçekleştirilmiştir. Gerçekleştirilen analize ilişkin sonuçlar Tablo 5' de sunulmuştur.

Tablo 5. Algılanan Hizmet Kalitesinin İş doyumuna Etkisini Tespite Yönelik Regresyon Analizi Sonuçları

\begin{tabular}{lrrlllll}
\hline Bağımsız değişken & $\mathbf{R}$ & $\mathbf{R}^{2}$ & $\begin{array}{l}\text { Düzeltilmiş } \\
\mathbf{R}^{2}\end{array}$ & $\mathbf{F}$ & $\boldsymbol{\beta}$ & $\mathbf{t}$ & $\mathbf{p}$ \\
\hline İş doyumu & .182 & .033 & .006 & 1,239 &,- 542 & $-1,113$ & .273 \\
\hline Bağımlı değişken: Hizmet kalitesi & & & & & & \\
\hline $\mathrm{p}<.05$ & & & & & &
\end{tabular}


Tablo 5 incelendiğinde çarşı ve mahalle bekçilerinin iş doyumları ile vatandaşların almış oldukları güvenlik hizmetine ilişkin kalite algıları arasında anlamlı bir ilişki olmadığı, oluşturulan regresyon modelinin istatistiksel olarak anlamlı olmadığı tespit edilmiştir $(=-0,542$ ve $p>005)$. Bu sonuca göre $\mathrm{p}<.005$ anlamlılık düzeyinde iş doyumu ile hizmet kalitesi algisı arasındaki ilişkinin anlamlı olmadığı ifade edilebilir. H1 hipotezi reddedilmiştir.

\section{Sonuç ve Tartışma}

Araştırmada, Mendoza ve Maldonado (2014), Chi ve Gürsoy (2009), Brown ve Lam, (2008), Payne ve Webber (2006), Homburg ve Stock (2004), Ugboro ve Obeng (2000), Schmit ve Allscheid (1995), Johnson ve arkadaşları (1994), Schlesinger ve Zornitsky (1991) ile Schneider ve Bowen'ın (1985) yapmış oldukları araştırma sonuçları doğrultusunda iş doyumu ve hizmet kalitesi algısı arasında pozitif yönlü ilişki olduğu varsayılmıştı. Ancak araştırma sonuçları bunu doğrulamamaktadır. Bu araştırma sonuçlarında bu iki değişken arasında herhangi bir anlamlı ilişki tespit edilememiştir. Bu sonuç Adcock (1999) ve Brown ve Mitchell' in yapmış oldukları araştırmalarda sonuçlarıyla uyuşmaktadır. Ancak, alan yazında bu iki değişken arasındaki ilişkiye yönelik sonuçlar birbiriyle örtüşmemektedir. Bununla birlikte bu iki değişken arasındaki ilişkiyi etkileyen faktörlerin bulunduğuna dair araştırma sonuçları da bulunmaktadır (Jeon ve Choi, 2012). Alan yazındaki hem iş doyumu ile hizmet kalitesi algısı arasındaki pozitif ilişki tespit eden araştırmalar, hem de bu iki değişken arasındaki ilişkide var olan diğer unsurlar göz önüne alınarak bu ilişkinin tüm boyutlarıyla ortaya konulması yönünde araştırma yapılması gerektiği değerlendirilmektedir.

Araştırmada Antalya ili Alanya ilçesinde görev yapan çarşı ve mahalle bekçilerinin genel ve dışsal iş doyum düzeylerinin orta, içsel iş doyum düzeylerinin ise yüksek seviyede olduğu tespit edilmiştir. İçsel iş doyumu, başarı, tanınma ve takdir edilme, işin sorumluluğu ve işin kendisi gibi çalışanın içsel niteliğine ilişkin tatminini ifade ederken, dışsal iş doyumu ise örgüt politikası ve yönetimi, denetim şekli, yönetici, çalışma arkadaşlarıyla ilişkiler ve çalışma koşulları gibi çalışanın çevresine ait tatmini göstermektedir (Weiss vd., 1967:4). Bu bağlamda çarşı ve mahalle bekçilerinin işlerini sevdikleri ve işin sorumluluklarından memnun oldukları, bu kapsamda da başarı duygusuna yönelik doyumlarının yüksek olduğu ancak, örgüte ilişkin yönetim 
tarzı, politika, denetim şekli gibi hususlarda yeteri kadar tatmin olamadıkları anlaşılmaktadır. İş doyumu örgütlerin etkinlik ve verimlilikleri üzerin doğrudan ilişkili (Şimşek vd., 2007:71) olmakla birlikte, etkinlik ve verimliliği etkileyen birçok iş tutumuyla da doğrudan ilişkilidir (Karataş ve Güleş, 2010; Çetin, 2006; Semercioğlu vd., 2012; Yılmaz, 2012; Aksoy Zor, 2019; Arslan ve Demir, 2017; Efraty vd., 1991; Orhaner ve Mutlu, 2018; Jeon ve Choi, 2012). Bununla birlikte düşük iş doyumu yüksek işe devamsızlık, çatışma ve stres, düşük zihinsel ve bedensel sağlık, düşük örgütsel bağlllık (Şimşek vd., 2007:71) gibi örgütler açısından birçok olumsuz neticeleri bulunmaktadır. Bu nedenle yöneticiler tarafından özenle üzerinde durulması gereken bir olgudur. Gerek çarşı ve mahalle bekçilerinin sunduğu güvenlik hizmetinin etkinlik ve verimliliğinin artırılması, gerekse de kendilerinin orta düzeyde oluşan iş doyumu düzeylerinin olumsuz neticelerle sonuçlanmaması amacıyla gerekli tedbirlerin alınması gerekmektedir. İş doyumu birçok bireysel ve örgütsel faktörden etkilenmektedir. Çarşı ve mahalle bekçilerinin özellikle dışsal doyum düzeylerinin düşüklüğü göz önüne alındığında çalışma koşulları, liderlik durumu, çalışanların kararlara katılım durumu, örgüt külttürü ve işin zorluk derecesi (Asunakutlu ve Avcı, 2010, s.98; Karataş ve Güleş, 2010, s.76; Başaran, 2000) gibi iş doyumunu etkileyen hususlar ele alınarak tedbirlerin ortaya konulması gerektiği değerlendirilmektedir.

Araştırmada Antalya ili Alanya ilçesinde yaşayan ve burada görevli çarşı ve mahalle bekçilerinden güvenlik hizmeti alan vatandaşların hizmet kalitesi algılarının orta düzeyde olduğu tespit edilmiştir. Araştırmada katılımcılara ayrıca güvenlik hizmeti aldıkları çarşı ve mahalle bekçisini hizmet verirken görüp görmedikleri sorusu da yöneltilmiştir. Araştırma sonuçlarında çarşı ve mahalle bekçilerini hizmet verirken gören vatandaşların hizmet kalitesi algısı yüksek, görmeyenlerin hizmet kalitesi algısı ise orta düzeyde tespit edilmiştir. Ayrıca bu iki örneklem arasında da anlamlı bir fark tespit edilmiştir. Bu sonuçlar aslında çarşı ve mahalle bekçileri tarafından sunulan güvenlik hizmetinin kalitesinin nispeten yüksek olmasına rağmen, kendileriyle ilişkiye girmemiş olan vatandaşlar tarafından daha düşük algılanması sebebiyle istenilen düzeyde gerçekleşmediğini ortaya koymaktadır. Bu sonuç çarşı ve mahalle bekçileri tarafından sunulan güvenlik hizmetinin kalitesine ilişkin algı üzerinde bu bekçilerin görünürlüklerinin önemli bir unsur olduğunu ortaya koymaktadır. Bu nedenle çarşı ve mahalle bekçilerinin sunduğu güvenlik 
hizmet kalitesinin istenilen ve beklenilen düzeyde vatandaşlar tarafından algılanabilmesi için öncelikle kendilerinin görünürlüklerinin artırılmasına yönelik çalışmalar yapılmalıdır. Çarşı ve mahalle bekçiliği müessesesi tarihi çok eskilere dayanan bir müessesedir. Hatta "Bekçi Baba" olarak tanınmaktadır. Sebebi ise tarih boyunca çarşı ve mahalle bekçilerinin mahalleliyle iç içe olmaları, onların tüm ihtiyaçlarına koşmaları ve ilgilenmeleridir. Böylelikle mahalleli, bekçiyi kendinden biri olarak görmüştür. Günümüzde de çarşı ve mahalle bekçilerinin güvenlik hizmeti sundukları halkla bütünleşme düzeyleri, sunulan güvenlik hizmet kalitesinin algı seviyesini belirleyecektir. Bununla birlikte sunulan hizmet kalitesini etkileyen güvenilirlik, heveslilik, yeterlilik, erişebilirlik, saygı, iletişim, inanılırlık, güvenlik ve müşteriyi anlamak gibi faktörler bulunmaktadır (Parasuraman vd., 1990, s.20-28). Çarşı ve mahalle bekçileri tarafından sunulan güvenlik hizmetinin kalitesini artırmak için kendilerine, yukarıdaki faktörler doğrultusunda, görev yaparken hizmet kalitesine ilişkin dikkat edilecek hususlar konusunda eğitim verilmesi gerektiği değerlendirilmektedir.

Araştırma Antalya ili Alanya ilçesinde gerçekleştirilmiştir. Başka il ve bölgelerde gerçekleştirilecek araştırma sonuçları farklılaşabilir. Bu nedenle araştırmanın bir kısıtı olarak değerlendirilebilir. Öte yandan Türkiye'de çarşı ve mahalle bekçiliği müessesesi uzun bir aradan sonra tekrar gündeme gelmiş ancak etkinlik ve verimliliği konusunda tartışmalar bulunmaktadır. Ancak bu tartışmalara rağmen çarşı ve mahalle bekçilerinin etkinlik ve verimliliklerinin tespitine yönelik araştırmaların kısıtlı olduğu görülmektedir. Bu nedenle bu yönde araştırma yapılmasında fayda bulunmaktadır. 


\title{
EXTENDED ABSTRACT
}

\section{The Effect of Job Satisfaction on The Perceived Quality of The Security Service Provided by The Bazaar and Neighborhood Wardens}

*

\author{
Mehmet Ali Tekiner - Uğur Demirci -Mustafa Harputlu \\ Police Academy - Police Department -Hatay governorate
}

The guard system, whose institutional foundations date back to the period of the Ottoman Conquest of İstanbul, continued to provide security services to the public under the name of "Bekçi Baba" in the Turkish Republic period. The importance given to the warden, whose rights and duties were regulated by the Law enacted in 1966, began to decrease due to various reasons in the 1970s, and the recruitment of guards to the state was stopped in 1993. However, in 2016, it was decided to re-start the formation of the bazaar and neighborhood wardens, within the framework of the idea that "measures can be taken against security problems with the patrol and the security practices that adopt the importance of the expectations of the society can be realized with the application of bazaar and neighborhood wardens".

Many positive and negative news have been published regarding the reintroduction and activativation of the bazaar and neighborhood wardens system in Turkey. Negative news appeared in the media that the citizens complained about the behavior of the guards, that the guards used excessive force and that the guards could be used as a means of interfering with the lifestyle of individuals. In this context, the quality of the security service offered by the bazaar and neighborhood wardens and how the citizens perceive this quality have come to the fore. In the researches conducted in this context, it has been revealed by various researches that the guards have positive contributions in the fight against crimes and they are welcomed in the eyes of the public, and the citizens feel more secure as a result of the system. However, there are also studies arguing that the revitalization of the warden system is not correct and that the powers given to them are worrisome. For this reason, it is important to reveal the quality level perceived by the 
citizens of the security service offered by the bazaar and neighborhood wardens, which have been re-implemented in Turkey.

Service quality, which is defined as an attitude that is satisfactory, but not of the same value, resulting from the comparison of customer expectations with current performance, plays a role on the success and failure of organizations. For this reason, it is important to determine the service quality for all organizations including public institutions. Organizations take the necessary measures by revealing whether the services they provide meet the expectations of the consumers, and if necessary, by concentrating on the elements that will increase the perception of this service quality. There are various factors that affect the perception of service quality. In the literature, it is stated that job satisfaction is one of the factors affecting the perception of service quality. In this context, it can be predicted that job satisfaction may be effective on the security service provided by the bazaar and neighborhood wardens in Turkey.

The research was carried out to answer the question "Is job satisfaction effective on the perceived quality of the security service provided by the bazaar and neighborhood wardens in Turkey?" For this purpose, a questionnaire was applied to the bazaar and neighborhood wardens working in the Alanya district of Antalya province and the citizens who received security services from them to determine their perceptions of job satisfaction and service quality.

Full count sample was conducted for bazaar and neighborhood wardens and random sampling was used for citizens. As a result of questionnaires, 38 data from bazaar and neighborhood wardens and 430 data from citizens were found analyzable. In this study, the job satisfaction scale developed by Weiss et al. (1967) and the SERVQUAL scale developed by Parasuraman et al. (1988) was used.

According to the results of the study, it was revealed that the relationship between job satisfaction and service quality perception is not significant. In the literature, the results of the research regarding the relationship between these two variables do not match each other. However, there are also research results showing that there are factors affecting the relationship between these two variables. It is considered that research should be conducted to reveal this relationship in all its dimensions, considering both the 
studies in the literature that detect a positive relationship between job satisfaction and the perception of service quality, and the other factors in the relationship between these two variables.

In this study it was also revealed that the level of internal satisfaction of bazaar and neighborhood wardens are high, the level of external and general satisfaction of them are moderate. While internal job satisfaction refers to the satisfaction of the internal quality of the employee such as success, recognition and appreciation, responsibility of the job and the job itself, external job satisfaction refers to the satisfaction of the employee's environment such as organizational policy and management, control style, manager, relations with colleagues and working conditions. Considering the low level of external satisfaction of the bazaar and neighborhood wardens, it is evaluated that measures should be taken by considering the issues affecting job satisfaction such as working conditions, leadership status, participation of employees in decisions, organizational culture and the degree of difficulty of the job.

These results reveal that although the quality of the security service offered by the bazaar and neighborhood wardens is relatively high, it is not realized at the desired level due to the low perception of it by the citizens who have not interacted with them. This result reveals that the visibility of these wardens is an important factor in the perception of the quality of the security service offered by the bazaar and neighborhood wardens. For this reason, in order for the citizens to perceive the security service quality offered by the bazaar and neighborhood wardens at the desired and expected level, first of all, efforts should be made to increase wardens own visibility.

The research was carried out in Alanya district of Antalya province. The results of the research to be carried out in other provinces and regions may differ. Therefore, it can be considered as a limitation of the research. On the other hand, the institution of bazaar and neighborhood warden has come to the agenda again after a long time, but there are discussions about its effectiveness and efficiency. However, despite these discussions, it is seen that the researches on the efficiency and productivity of the bazaar and neighborhood watchmen are limited. Therefore, it is beneficial to conduct research in this direction in Turkey. 


\section{Kaynakça / References}

Adcock, B.P. (1999). The Role of Organizational Citizenship Behavior in The Linkage of Employee and Customer Satisfaction. (Yayınlanmamış Doktor Tezi). South Florida Üniversitesi.

Akbaba A., Gürü, B. E., Yaran, M. ve Çimen, H. (2006). Öğrencilerin öğretim elemanları ile ilgili kalite beklentileri: Akçakoca Turizm İşletmeciliği ve Otelcilik Yüksekokulu Örneği. Anatolia. Turizm Araştırmalan Dergisi, 17 (1), 921.

Akgündüz, Y. (2013). Konaklama İşletmelerinde İş Doyumu, Yaşam Doyumu ve Öz Yeterlilik Arasındaki İlişkinin Analizi. Celal Bayar Üniversitesi Sosyal Bilimler Dergisi, 11, 180-204.

Aksoy Zor, E. (2019). Sını Öğretmenlerinin Umutsuzluk Düzeyleri İle İş Doyumları, Işs Yaşam Kaliteleri ve Tükenmişlik Düzeyleri Arasındaki İlişkinin Incelenmesi. (Yayınlanmamış Yükseklisans Tezi), Trabzon Üniversitesi Lisansüstü Eğitim Enstitüsü, Trabzon.

Aktaş, H. ve Şimşek, E. (2015). Bireylerin Örgütsel Sessizlik Tutumlarına İş Doyumu ve Duygusal Tükenmişlik Algilarının Rolü. Uluslararası Yönetim İktisat ve İsletme Dergisi, 11(24), 205- 230.

Esin, A. (2002). ISO 9001:2000 Işı̆̆ı Altında Hizmette Toplam Kalite. Ankara: METU Press ODTÜ Geliştirme Vakfi Yayını.

Altan, Ş. ve Atan, M. (2004). Bankacilık Sektöründe Toplam Hizmet Kalitesinin SERVQUAL Analizi ile Ölçümü. Gazi Üniversitesi İktisadi ve İdari Bilimler Fakültesi Dergisi, 6(1), 17-32.

Altan, S.., Ediz, A. Ve Atan, M., (2003). Servqual Analizi ile Toplam Hizmet Kalitesinin Ölçümü ve Yüksek Eğitimde Bir Uygulama. 12. Ulusal Kalite Kongresi, 13 - 15 Ekim, İstanbul. İstanbul, Kal Der-Türkiye Kalite Derneği Lütfi Kırdar Kongre ve Sergi Sarayı.

Altınel, G. (2009) Hizmet Kalitesi, Hizmet Kalitesinin Ölçümü ve Bankacılık Sektöründe Bir Uygulama. (Yayınlanmamış Yüksek Lisans Tezi). Gebze Yüksek Teknoloji Enstitüsü, Gebze.

Arslan, E.T. ve Demir, H. (2017). İşe Angaje Olma ve İş Tatmini Arasındaki İlişki: Hekim ve Hemşireler Üzerine Nicel Bir Araştırma. Yönetim ve Ekonomi, 24(2), 371-389.

Asunakutlu, T. ve Avcı, U. (2010). Aile İşletmelerinde Nepotizm Algısı ve İş Tatmini İlişkisi Üzerine Bir Araştırma. Süleyman Demirel Üniversitesi İktisadi ve İdari Bilimler Fakültesi Dergisi, 15 (2), 93-109. 
Barbak, A. (2017). 6360 Sayılı Kanun ve İllerde İç Güvenlik Yönetiminde Değişim. Mehmet Akif Ersoy Üniversitesi Sosyal Bilimler Enstitüsü Dergisi, 9 (19), 231253.

Baron, R. A. ve Greenberg, J. (1990). Behavior in Organizations. (2nd Ed.). Massachussets: Allyn and Bacon.

Başaran, İ. E. (2000). Örgütsel Davranış, İnsanın Üretim Gücü, Ankara: Feryal Matbaası.

Berry L. L., Parasuraman, P. A. ve Zeithaml, V. A. (1988). The Service-Quality Puzzle. Business Horizon, September-October, 35-43.

Brown, K. A. ve Mitchell, T.R. (1993). Organizational Obstacles: Links with Financial Peformance, Customer Satisfaction, and Job Satisfaction In A Service Environment. Human Relations, 46 (6), 725-757.

Brown, S.P. ve Lam, S.K. (2008). A Meta-Analysis of Relationships Linking Employee Satisfaction to Customer Responses. Journal of Retailing, 84(3), 243-255.

Brysland, A. ve Curry, A. (2001). Service Improvements in Public Services Using SERVQUAL, Managing Service Quality, 11(6), 389-401.

Atabeyoğlu, C. (1993). "Bekçiler", Dünden Bugüne İstanbul Ansiklopedisi 2. İstanbul: Kültür Bakanlığı ve Tarih Vakfı Ortak Yayını.

Chi, C.G. ve Gürsoy, D. (2009). Employee Satisfaction, Customer Satisfaction, and Financial Performance: An Emprical Examination. International Journal of Hospitality Management, 28(2), 245-253.

Churchill, G.A., Ford, N.M. ve Walker, O.C. (1974). Measuring The Job Satisfaction of İndustrial Salesmen. Journal of Marketing Research, 11, 323-32.

Çelik, İ. (2010) Yüksek Öğrenimde Hizmet Kalite Algısının Ölçümü: Yüksek Lisans Öğrencileri Üzerinde Bir Araştırma. (Yayınlanmamış Yüksek Lisans Tezi). Eskişehir Osmangazi Üniversitesi, Eskişehir.

Çetin, M.O. (2006). The Relationship Between Job Satisfaction, Occupational and Organizational Commitment of Academics. Journal of American Academy of Business, 8(1), 78-88.

Çiçek, R. ve Doğan, İ.C. (2009). Müşteri Memnuniyetinin Artırılmasında Hizmet Kalitesinin Ölçülmesine Yönelik Bir Araştırma: Niğde İli Örneği. Afyon Kocatepe Üniversitesi I.I.I.B.F. Dergisi, CXI,SI, 199-217.

Çiftçi, A. G. (2006) Hizmet Kalitesi ve Bankacllk Sektöründe Hizmet Kalitesi Ölçümüne Yönelik Bir Uygulama, (Yayınlanmamış Yüksek Lisans Tezi), Dokuz Eylül Üniversitesi, İzmir. 
Çobanoğlu, Ş.A. ve Bek, A. (2019). Çarşı ve Mahallelerde Yardımcı Genel Kolluk Hizmeti Olarak Bekçilik. (Bildiri). 13.Uluslararası Kamu Yönetimi Sempozуити. 1755-1767.

Dalgıç, A. (2013). Hizmet Sektöründe Hizmet Kalitesinin Ölçümü ve Hizmet Kalitesini Etkileyen Faktörler. (Yayınlanmamış Yüksek Lisans Tezi). Adnan Menderes Üniversitesi Sosyal Bilimler Enstitüsü. Aydın.

Demirbağ, O. ve Yozgat, U. (2016). Hizmet Alan (Müşteri) ve Hizmet Veren (Çalışan) Perspektifinden Hizmet Kalitesinin SERVQUAL Yöntemiyle Ölçümü: Bir Kamu Kurumu Olarak PTT İncelemesi. Uluslararası Bilimsel Araştırmalar Dergisi, 1 (1), 78-89.

Doğan, C. (2019). Eski İstanbul'da Mahalle Bekçisi ve III.Meşrutiyet'te Bekçi Teşkilatının Düzenlenmesi Bağlamında Mahalle Bekçileri Nizamnamesi (19081918), Osmanlı Mirası Araştırmaları Dergisi, 6(14), 257-273.

Doyle, P. ve Stern, P. (2006). Marketing Management and Strategy, (Forth Ed.), Essex: Pearson Education.

Efraty, D., Sirgy, M. J. ve Claiborne C. B. (1991). The Effects of Personal Alienation on Organizational Identification: A Quality-Of-Work-Life Model. Journal of Business and Psychology, 6 (1), 57-78.

Erdoğan,İ. (1999). İşletme Yönetiminde Örgütsel Davranış. İstanbul: İşletme Fakültesi Yayınları, Yayın No:5.

Erman, R.B., Özcan, O., Yetkin, E., Börekçi, E.B. ve Üzeltürk, S.Ş.T. (2020). Çarşı ve Mahalle Bekçileri Kanun Teklifi Hakkında Tespit, Düşünce ve Eleştiriler. E-kitap, İstanbul. ISBN: 978-975-307-105-5.

Ersöz, S., M. Pınarbaşı, A. K. Türker, ve M. Yüzükırmızı. (2009). Hizmet Kalitesinin Servqual Metodu ile Ölçümü ve Sonuçların Yapısal Esitlik Modelleri ile Analizi: Ögretmen Evi Uygulaması. Int.J.Eng.Research and Development, 1, 19-27.

Evliya Çelebi Mehmed Zillî ibn-i Derviş (1898)., Evliya Çelebi Seyahatnamesi I (Haz. Ahmed Cevdet). İkdam Matbaası, Dersaadet 1314

Şahin, E. (2018). Çarşı ve Mahalle Bekçileri. Ankara: Türk Polis Teşkilatı Yayınları.

George D, ve Mallery P. (2003). SPSS for Windows Step by Step: A Simple Guide and Reference. 11.0 update (4th ed.). Boston: Allyn \& Bacon,

Gökçe, A.F. ve Kulu, S. (2019). Çarşı ve mahalle Bekçilerinin Asayişe Olan Etkileri: Gaziantep Ili Ve Erzurum İli Örneği. (Tam Metin Bildiri). 17.Uluslararası Kamu Yönetimi Forumu. 151-161.

Grönroos, C. (1983). Innovative Marketing Strategies and Organization Structures for Service Firms. Emerging Perspectives of Services Marketing, 9-21. 
Gülmez, M. ve Kitapçı, O. (2008) Hastane Hizmet Kalitesi ve Bir Uygulama, H.Ü. İktisadi ve İdari Bilimler Fakültesi Dergisi, 26,(1), 165-186.

Han, S. L. ve S. Baek, (2004). Antecedents and Consequences of Service Quality in Online Banking: An Application ff The SERVQUAL Instrument. Advances in Consumer Research, 31(1), 208-214.

Hançer, M. ve George, R. T. (2003). Job Satisfaction of Restaurant Employees: An Emprical İnestigation Using The Minnesota Satisfaction Questionnaire. Journal of Hospitality\&Tourism Research, 27 (1), 85-100.

Hassan, S.A. (2019). Hizmet Kalitesinin Müşteri Sadakati ve Müşteri Memnuniyeti Üzerinde Etkisi: Cep Telefonu Sektöründe Konya-Kerkük Kıyaslaması. (Yayınlanmamiş Doktora Tezi). Selçuk Üniversitesi Sosyal Bilimler Enstitüsü, Konya.

Homburg, C. ve Stock, R.M. (2004). The Link between Salespeople's Job Satisfaction and Customer Satisfaction in A Business-To-Business Context: A Dyadic Analysis. Journal of the Academy of Marketing Science, 32, https://doi.org/10.1177/0092070303261415

Gülşen, İ. H. (1999). Çarşı ve Mahalle Bekçileri: Bekçi Baba. Polis Dergisi, 5(19). İçişleri Bakanlığı (2019). Çarşı ve Mahalle Bekçiliği Saha Araştırması.

Jeon, H. ve Choi, B. (2012). The Relationship between Employee Satisfaction and Customer Satisfaction. Journal of Services Marketing, 26(5), 332-341.

Johnson R.H., Ryan A.M. ve Schmit M.J. (1994). Employee Attitudes and Branch PerFormance at Ford Motor Credit. In Rotchford N (Chair), Linking Employee Survey Data to Organizatwnal Outcome Measures. Practitioner Forum conducted at the Ninth Annual Conference of the Society of Industrial and Organizational Psychol- ogy, Nashville, TN.

Karataş, S. ve Güleş, H. (2010). İlköğretim Okulu öğretmenlerinin İş Tatmini ile Örgütsel Bağlılığı Arasındaki İlişki. Uşak Üniversitesi Sosyal Bilimler Dergisi, 3 (2), 74-89.

Kılıç, S. (2016). Cronbach'ın Alfa Güvenilirlik Katsayısı. JMOOD, 6(1), 47-48.

Kış, A., Şad, S.N., Özer, N. ve Atik, S. (2016). A Meta-Analysis of The Relationship between Burnout and Job Satisfaction of Educational Stakeholders. Erzincan Üniversitesi Ĕ̈itim Fakültesi Dergisi, 18(1), 160-183.

Koçu, R. E. (1973). Bedesten ve Kapalı Çarşı. Hayat Tarih Mecmuası, l(1), 57-58.

Kotler, P. ve Keller, K. L. (2016) Marketing Management, (15. Bask1). Essex: Pearson.

Kurt, M. ve Yaşar Uğurlu, Ö. (2007). Yeni Kamu Yönetimi ve Yeni Kamu Yönetimi Yaklaşımının Gelişiminde Avrupa Birliği'nin Rolü: İlerleme Raporları İçerik Analizi. Afyon Kocatepe Üniversitesi İİ.B.F. Dergisi, 9 (2), 81-109. 
Lehtineni U. ve Jarmo R. L. (1983). Service Quality: A Study of Quality Dimensions. Working Paper, Helsinki University Service Managent Institute, Helsinki Locke, E.A. (1976). The Nature and Consequences of Job Satisfaction. in Dunnette, M.D. (Ed.), Handbook of Industrial and Organizational Psychology, Rand McNally, Chicago, IL, 12971349.

Mendoza, M.L. ve Maldonado, C.O. (2014). Meta-Analytic of The Relationship between Employee Job Satisfaction and Customer Satisfaction. Suma de Negocios, 5(11), 4-9.

Noémi L. (2008). Yakından Korunan Düzen: Abdülhamid Devrinden İkinci Meşrutiyet Dönemine Bekçi Örneği. Osmanlı'da Asayiş, Suç ve Ceza 18.-20. Yüzyıllar. (Der: Noémi Lévy ve Alexandre Tourmarkine), Tarih Vakfı Yurt Yayınları, İstanbul, 138.

Normann, R. (1991). Service Management: Strategy and Leadership in Service Business. Chichester: John Wiley \& Sons.

Oran, N.B. (1989). A Study on Job Satisfaction of A Group of Academical Staff in Marmara University. (Yayınlanmamış Yüksek Lisans Tezi). İstanbul: Marmara Üniversitesi Sosyal Bilimler Enstitüsü.

Ordu, A. (2016). Lise Öğretmenlerinin İş Doyumları ve Bireysel Performansları Arasındaki İlişki. Mustafa Kemal Üniversitesi Sosyal Bilimler Enstitüsü Dergisi, 13(36), 1-19.

Orhaner, E. ve Mutlu, S. (2018). Sağlık Personelinin İş Tatmininin Motivasyon Üzerine Etkisi. Uluslararası Sağlık Yönetimi ve Stratejileri Araştırma Dergisi, 4(1), 74-93.

Özgen, H., Öztürk, A. ve Yalçın, A. (2002). İnsan Kaynakları Yönetimi, Adana: Nobel Yayınevi.

Öztuna, Y. (1978). Büyük Türkiye Tarihi, Türk Siyaset Tarihi ve Türk Medeniyeti Tarihi. Ötüken yayınevi.

Parasuraman, A. P, Zeithaml V. A., ve Berry, L. L.(1985). A Conceptual Model of Service Quality and Its Implications for Future Research. Journal of Marketing, 49(4), 41-50.

Parasuraman, A., Zeithaml, V.A. ve Berry, L. (1990). Delivering Quality Service- Balancing Customer Perceptions and Expectations. The Free Pres, New York.

Payne, S.C. ve Webber, S.S. (2006). Effects of Service Provider Attitudes and Employement Status on Citizenship Behaviors and Customers Att,Tudes and Loyalty Behavior. Journal of Applied Psychology, 91 (2), 365-378. 
Podsakoff, P. M., MacKenzie, S. B. ve Podsakoff, N. P. (2012). Sources of Method Bias in Social Science Research and Recommendations on How to Control It. Annual Review of Psychology, 63, 539-569.

Podsakoff, P. M., MacKenzie, S. B., Lee, J. Y. ve Podsakoff, N. P. (2003). Common Method Biases in Behavioral Research: A Critical Review of The Literature and Recommended Remedies, Journal of Applied Psychology, 88, 879-903.

Polis Akademisi Başkanlı̆̆ (2019). Güvenliğin Kurumsal Yönetiminde Destekleyici Polislik: Bekçilik Örneği. Polis Akademisi Yayınları. Rapor No:32. ISBN: 978605-7822-33-8.

Sasser, W. E., Olsen R. P. ve Wyckoff, D. D. (1978). Management of Service Operations: Text and Cases. Boston: Auyn \& Bacon.

Schlesinger, L.A. ve Zornitsky, J. (1991). Job Satisfaction, Service Capability, and Customer Satisfaction: An Examination of Linkages and Management Implications. Human Resource Planning, 14,141-150.

Schmit, M.J. ve Allscheid, S.P. (1995). Employee Attitudes and Customer Satisfaction: Making Theoretical and Empirical Connections. Personnel Psychology, 48, 521-536.

Schneider, B. ve Bowen, D.E. (1985). Employee and Customer Perceptions of Service in Banks: Replication and Extension. Journal of Applied Psychology, 70,423-433.

Semercioğlu, S., Tengilimoğlu, D. ve Semercioğlu, M.G. (2012). Özel ve Kamu Hastanelerinde Çalışan Tıbbi Sekreterlerin İş Doyumu ve Örgütsel Güven Düzeylerinin Karşılaştırılmasına Yönelik Bir Alan Çalışması. Gümüşhane Üniversitesi Sağllk Bilimleri Dergisi, 1 (4), 225-238.

Silvestro, R. ve Cross, S. (2000). Appliying The Service Profit Chain in A Retail Environment. International Journal of Service Industry Management. 11(3), 244268.

Spiro, R.L. ve Weitz, B.A. (1990). Adaptive Selling: Conceptualization, Measurement, and Nomological Validity. Journal of Marketing Research, 27(1), 61-69.

Şahin, E. (2018). Çarşı ve Mahalle Bekçileri. Türk Polis Teşkilatı Yayınları. ISBN:978605-149-946-8.

Şahin, E. (2005). Özel Güvenlik Teşkilatı, Halk Tarafindan Benimsenme Konusunda Geçmişimizdeki Özel Bekçi Teşkilatın Yakalayabilir mi?. II. Ulusal Özel Güvenlik Sempozyumu, Kocaeli: Kocaeli Üniversitesi Matbaası.

Şimşek, M.Ş., Akgemci, T. ve Çelik, A. (2007). Davranış Bilimlerine Giriş ve Örgütlerde Davranıs. Ankara: Gazi Kitabevi. 
Tabachnick, B.G. ve Fidell, L.S. (2013). Using Multivariate Statistics (sixth ed.) Pearson, Boston

Turunç, Ö., Tabak, A., Şeşen, H. ve Türkyılmaz, A. (2010). Çalışma Yaşamı Kalitesinin Prosedür Adaleti, İş Tatmini, İ̧s Stresi ve İşten Ayrılma Niyetine Etkisi. "İ̧̧ǚç" Endüstri Illişkileri ve İnsan Kaynaklarn Dergisi, 12(2), 117-134.

Ugboro, I.O. ve Obeng, K. (2000). Top Management Leadership, Employee Empowerement, Job Satisfaction, and Customer Satisfaction in TQM Organizations: An Emprical Study. Journal of Quality Management, 5(2), 247-272.

Vieira, J. A. (2005). Skill Mismatches and Job Satisfaction. Economic Letters, 89(1), 3947.

Weiss, D.J., Dawis, R.W., England, G.W. ve Lofquist, L.H. (1967). Manual for the Minnesota Satisfaction Quesitionnaire. http://vpr.psych.umn.edu/sites/g/files/pua2236/f/monograph_xxii__manual_for_the_mn_satisfaction_questionnaire.pdf

Wisniewski, T. (2001). Using SERVQUAL to Assess Customer Satisfaction with Public Sector Services. Managing Service Quality, 11(6), 380-388.

Yağcl, M. İ. ve Duman, T. (2006). Hizmet Kalitesi-Müşteri Memnuniyeti İlişkisinin Hastane Türlerine Göre Karşlaştırılması: Devlet, Özel ve Üniversite Hastaneleri Uygulaması. Doğuş Üniversitesi Dergisi, 7(2), 218-238.

Yazıcıoğlu, Y. ve Erdoğan, S. (2004). Spss Uygulamalı Bilimsel Araştırma Yöntemleri. Ankara: Detay Yayıncilı.

Yılmaz, İ. (2011). Müze ziyaretçilerinin Hizmet Kalitesi Algılamaları: Göreme Açı Hava Müzesi Örneği. Anatolia: Turizm Araştırmaları Dergisi, 22(2), 183-193.

Yılmaz, K. (2012). İlköğretim Okulu Öğretmenlerinin İş Doyumu Düzeyleri ile Örgütsel Vatandaşlık Davranışları Arasındaki İlişki. AJESI, 2(2), 1-14.

Yılmaz, V., Filiz, Z. ve Yaprak B. (2007). SERVQUAL Yöntemiyle Yükseköğretimde Hizmet Kalitesinin Ölçülmesi. Anadolu Üniversitesi Sosyal Bilimler Dergisi, 7(1), 299-316.

Yücel, M. (2013). Toplam hizmet kalitesinin SERVQUAL Analizi ile Ölçümü: Bankacllık Sektöründe Bir Araştırma. Electronic Journal of Social Sciences, 12(44), 82-106. 


\section{Kaynakça Bilgisi / Citation Information}

Tekiner, M.A., Demirci, U. ve Harputlu, M. (2020). Çarşı ve mahalle bekçilerinin sundukları güvenlik hizmetinin algılanan kalitesine iş doyumunun etkisi. OPUS-Uluslararası Toplum Araştırmaları Dergisi, 17(38), 4928-4957. DOI: 10.26466/opus.796313 